\title{
Evaluation of occupational and patient dose in cerebral angiography procedures*
}

\author{
Avaliação da dose ocupacional e de pacientes adultos em procedimentos de angiografia cerebral
}

\author{
Neuri Antonio Lunelli ${ }^{1}$, Helen Jamil Khoury ${ }^{2}$, Gustavo Henrique Vieira de Andrade ${ }^{3}$, Cari Borrás ${ }^{4}$
}

\begin{abstract}
Objective: The present study was aimed at estimating the doses received by physicians and patients during cerebral angiography procedures in a public hospital of Recife, PE, Brazil. Materials and Methods: The study sample included 158 adult patients, and during the procedures the following parameters were evaluated: exposure parameters (kV, $\mathrm{mAs}$ ), number of acquired images, reference air kerma value $\left(K_{a, r}\right)$ and air kerma-area product $\left(P_{K A}\right)$. Additionally, the physicians involved in the procedures were evaluated as for absorbed dose in the eyes, thyroid, chest, hands and feet. Results: The results demonstrated that the doses to the patients' eyes region were relatively close to the threshold for cataract occurrence. As regards the physicians, the average effective dose was $2.6 \mu \mathrm{Sv}$, and the highest effective dose recorded was $16 \mu \mathrm{Sv}$. Conclusion: Depending on the number of procedures, the doses received by the physicians may exceed the annual dose limit for the crystalline lenses $(20 \mathrm{mSv})$ established by national and international standards. It is important to note that the high doses received by the physicians are due to the lack of radiation protection equipment and accessories, such as leaded curtains, screens and protective goggles.
\end{abstract}

Keywords: Dosimetry; Interventional radiology; Cerebral angiography.

Resumo Objetivo: Este trabalho teve como objetivo estimar os valores de doses de radiação recebidas por médicos e pacientes em procedimentos de angiografias cerebrais realizados em um hospital público na cidade de Recife, PE. Materiais e Métodos: Foram avaliadas as doses recebidas por 158 pacientes. Durante os procedimentos clínicos, foram registrados os parâmetros de irradiação ( $\mathrm{kV}, \mathrm{mAs})$, número de imagens, valor do kerma ar de referência $\left(\mathrm{K}_{\mathrm{a}, \mathrm{r}}\right)$ e do produto kerma ar-área $\left(\mathrm{P}_{K_{A}}\right)$. Também foi efetuado estudo da dose absorvida na região dos olhos, tireoide, tórax, mãos e pés dos médicos que realizaram os procedimentos intervencionistas. Resultados: Os resultados mostraram que as doses na região dos olhos dos pacientes podem chegar a valores próximos ao limiar para a ocorrência de catarata. A dose efetiva média nos médicos foi $2,6 \mu \mathrm{Sv}$, sendo que o maior valor encontrado foi $16 \mu \mathrm{Sv}$. Conclusão: Dependendo do número de procedimentos mensais, as doses recebidas pelos médicos podem exceder o novo limite de dose anual para o cristalino, que é de $20 \mathrm{mSv}$, estabelecido pelos órgãos nacionais e internacionais. As altas doses recebidas pelos médicos são decorrentes da ausência de acessórios de radioproteção, tais como cortinas, telas e óculos plumbíferos.

Unitermos: Dosimetria; Radiologia intervencionista; Angiografia cerebral.

Lunelli NA, Khoury HJ, Andrade GHV, Borrás C. Evaluation of occupational and patient dose in cerebral angiography procedures. Radiol Bras. 2013 Nov/Dez;46(6):351-357.

\section{INTRODUCTION}

Interventional radiology is a specialty which relies on percutaneous technologies, utilization of catheters coupled with radiological techniques and neurological and neurosurgical knowledge for the diagnosis and treatment of central nervous system

* Study developed in the Department of Nuclear Energy at Universidade Federal de Pernambuco (UFPE), Recife, PE, Brazil.

1. PhD, Technical and Technological Education Teacher at Universidade Tecnológica Federal do Paraná (UTFPR), Pato Branco, PR, Brazil.

2. PhD, Full r Professor, Universidade Federal de Pernambuco (UFPE), Recife, PE, Brazil.

3. MD, Specialist in Therapeutic Neuroradiology, Interventional Radiologist, Angiorad/IMIP, Recife, PE, Brazil.

4. PhD, Radiological and Health Physics Services, Washington, DC, USA. disorders. The technology of medical imaging, such as digital cerebral angiography and three-dimensional (3D) mapping of brain vessels, has achieved relevant advances in interventional neuroradiology. A number of recent publications in Brazil highlight the importance of neuroradiology for diagnosis and treatment of several diseases $^{(\mathbf{1 - 1 0})}$.

In spite of their benefits, such procedures may expose both patient and medical team to high radiation doses. Many

Mailing Address: Dr. Neuri Lunelli. Grupo de Dosimetria e Instrumentação Nuclear. Avenida Professor Luiz Freire, 1000 Cidade Universitária. Recife, PE, Brazil, 50740-540. E-mail: neuri@utfpr.edu.br.

Received August 31, 2012. Accepted after revision March 25, 2013. studies have demonstrated that several procedures, due to their complexity and long fluoroscopy times, result in doses above the deterministic effect threshold on some skin areas, causing skin injuries ${ }^{(\mathbf{1 1 - 1 4})}$. The study developed by Mooney et al. ${ }^{(\mathbf{1 4})}$, for example, describes the case of two patients who had lost hair after being submitted to embolization of arteriovenous malformations. Additionally, new studies on tissue reactions have shown that, depending upon individual sensitivity, injuries to radiosensitive organs may occur even with doses below the previously defined thresholds ${ }^{(15)}$.

Considering the rapid development of all technologies involved in interventional procedures, it is important to be aware of 
the radiation level to which the patient is exposed, in order to guarantee his/her safety. Despite the relevance of the subject, there is little investigation on radiation exposure in a wide variety of interventional neuroradiology procedures. So far, there are no standardized values for reference levels to guide neurointerventionists about the relative radiation exposure of their patients ${ }^{(\mathbf{1 6})}$. At the same time, physicians who perform interventional procedures are among those professionals who receive the highest radiation doses recorded in hospital procedures. In normal working conditions, scattering radiation around the patient is high, and in the absence of individual protection devices, the physician is submitted to a high level of radiation which, depending upon the work load, may cause injuries to the eyes after a few years ${ }^{(17)}$.

The present study was aimed at assessing cerebral angiography procedures performed in adult patients at a hospital in the city of Recife, PE, Brazil, with the purpose to estimate the doses received by patients and physicians due to these procedures.

\section{MATERIALS AND METHODS}

The present study was undertaken at the Hemodynamics Unit of the Instituto de Medicina Integral Professor Fernando Figueira (IMIP), in Recife, PE, Brazil, in cooperation with the neuroradiology medical team. The study was approved by the Ethical Committee in Research of the institution. The patients or guardians who accepted to participate in the study were duly informed on the risks and benefits of the investigation and signed a term of free and informed consent, according to the requirements of CNS Resolution 196/96, which regulates research involving human beings in Brazil ${ }^{(\mathbf{1 8})}$.

In the present study, 158 cerebral angiographic procedures performed in 88 male and 70 female, adult patients were investigated.

The equipment used at the institution for interventional neuroradiology procedures is a Siemens Artis Zee angiographic apparatus equipped with a flat panel image detector receptor. Before measurements were made in patients, tests have been performed in order to verify the working con- ditions of the x-ray equipment. The procedures used in such tests were based on the requirements of Agência Nacional de Vigilância Sanitária (Anvisa) (the Brazilian Health Surveillance Agency) ${ }^{(\mathbf{1 9})}$, on the protocol from the American Association of Physicists in Medicine ${ }^{(\mathbf{2 0 )}}$ and on the equipment manufacturer's specifications ${ }^{(21)}$. The obtained results have shown that the equipment's performance met the requirements of applicable standards.

For the study of the dose received by the patient, the following data were collected during each procedure:

a) patients' personal data and type of procedure used;

b) irradiation parameters and adopted protocols;

c) fluoroscopy time, number of acquired images and sequences and existence or not of rotational acquisition (for 3D or tomographic reconstruction);

d) angle and rotation values for each view, with respective size of the magnification field;

e) air kerma at the interventional reference point $\left(\mathrm{K}_{\mathrm{a}, \mathrm{r}}\right)$;

f) air kerma-area product $\left(\mathrm{P}_{\mathrm{KA}}\right)$.

The evaluated procedures were randomly selected among those performed at the hospital.

\section{Dosimetry in patients}

In order to estimate the dose received by the patient in cerebral angiographies, $\mathrm{P}_{\mathrm{KA}}$ and $\mathrm{K}_{\mathrm{a}, \mathrm{r}}$ values were measured. The $\mathrm{K}_{\mathrm{a}, \mathrm{r}}$ was obtained from the value provided by the equipment with basis on the patient's irradiation geometry and exposure parameters selected during the clinical procedure. Such quantity is defined for the reference point of the interventional procedure (IRP interventional reference point), which by definition, is located $15 \mathrm{~cm}$ away from the isocenter towards the $\mathrm{x}$-ray tube ${ }^{(\mathbf{2 2})}$. The International Electrotechnical Commission defines IRP as a representative location on the patient's skin, but, depending upon the patient's thickness, such point may not corresponds to the e patient's skin. The $\mathrm{P}_{\mathrm{KA}}$ value was obtained with the parallel plates ionization chamber installed at the exit of the collimator, which intercepts the primary $\mathrm{x}$-ray beam. The reading of the measurement performed with such an ionization chamber corresponds to the air kerma and the cross section area of the beam on the point where the chamber is located. The $\mathrm{P}_{\mathrm{KA}}$ values provided by the ionization chamber were corrected by means of a previously determined factor, which corrects the contribution of scattered radiation due to the collimation system of the equipment. The utilized factor was 0.797 .

In order to evaluate the skin entrance dose on the patient, studies with thermoluminescent dosimeters (TLDs) were performed in only 37 of the patients (17 men and 20 women). Such study was not performed with all patients due to the limited number of available dosemeters. For each procedure, four pairs of TLDs type LiF:Mg;Ti (TLD-100) with dimensions of $3 \times 3 \times 1 \mathrm{~mm}$, which were encapsulated in pairs in small numbered plastic pouches and placed on the following sites of the patient's body, as shown on Figure 1: eyes sides, on the glabella (between the eyebrows) and on the thyroid. After exposure of the dosemeters on the patients, the readings were performed with a $2800 \mathrm{M}$ Victoreen readout device. The TLDs were previously calibrated at Laboratório de Metrologia das Radiações Ionizantes-DEN/ UFPE using an x-ray beam with quality equivalent to the beam used in the interventional radiology apparatus. A calibration curve made possible to convert the dosemeters' readings into air kerma.

\section{Occupational dosimetry}

The present study also evaluated the occupational dose on the physicians who performed 31 cerebral angiographies. For such an evaluation, the air kerma was measured with TLD-100 dosimeters placed on nine points of the physicians' bodies. The dosimeters were encapsulated in pairs and attached on each of the nine points, as shown on Figure 2. The locations were selected for being considered representative for the calculation of the effective dose, as well as for the assessment of the equivalent dose in radiosensitive organ regions, such as thyroid and eyes.

The dosimeters were attached with adhesive tape, and the measurement points were distributed as follows:

- three on the face: one next to the right eye, one on the glabella and another 


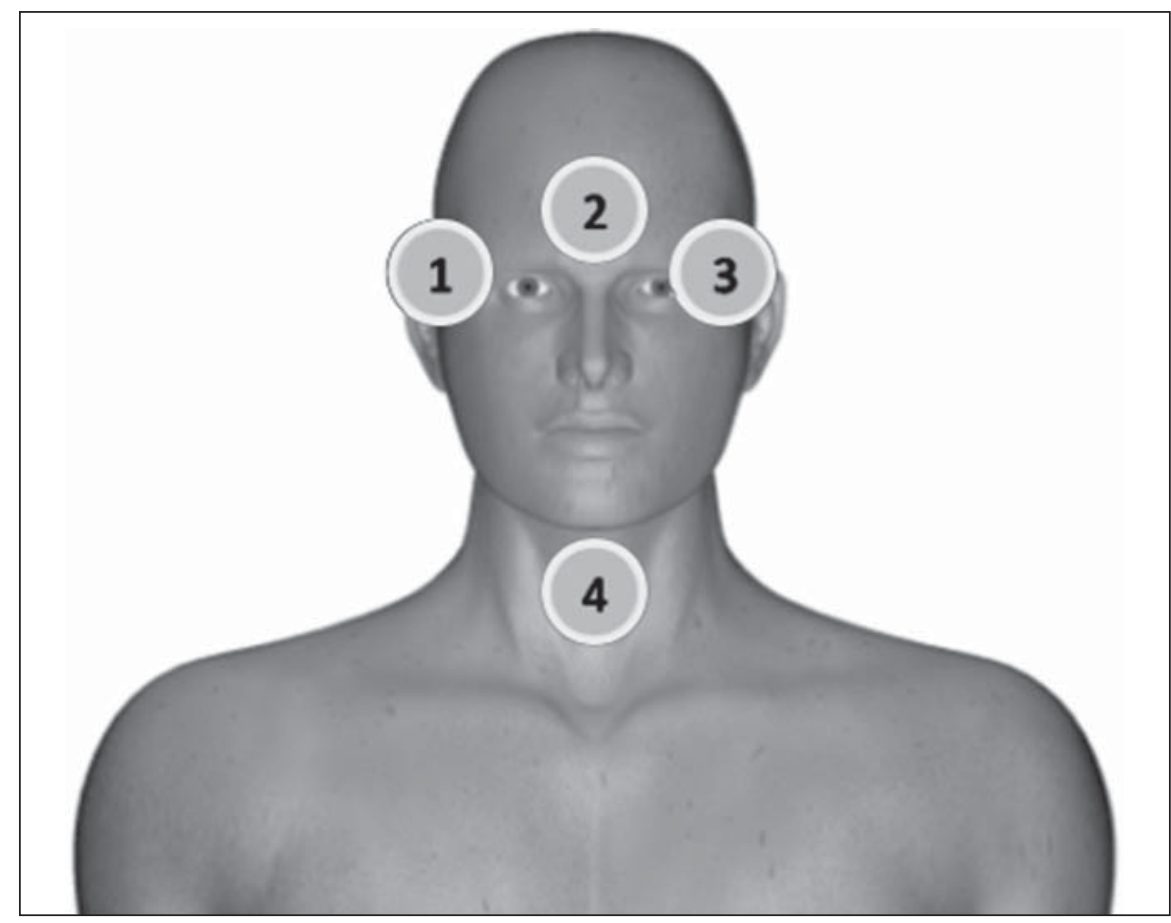

Figure 1. Positioning of dosimeters on the patient.

next to the left eye-dosimeters 1,2 , and 3 , respectively;

- one on thyroid region, externally attached over the thyroid protector - dosimeter 4;

- one on the chest region, under the apron - dosimeter 5;

- two for the hands, at the wrist region under the glove, one for each hand - dosimeters 6 and 7 ;

- two for the feet - dosimeters 8 and 9 . By using the Nilklason algorithm ${ }^{(23)}$ the effective dose on the physicians was calculated with basis on the air kerma measurements obtained from two TLDs, one positioned on the external surface of the thyroid protector, and the other under the apron on the chest region. The measurements obtained with those dosimeters were corrected for operational quantities $\mathrm{H}_{\mathrm{P}}(0.07)$ and $\mathrm{H}_{\mathrm{P}}(10)^{(\mathbf{2 4 )}}$. The algorithm proposed by Nilklason is the following:

$$
E=0.02\left(H_{O}-H_{U}\right)+H_{U}
$$

where: $H_{O}$ is the value of air kerma obtained from the reading of the dosimeter taped on the thyroid protector (TLD 4), converted into $\mathrm{H}_{\mathrm{P}}(0.07)$; and $H_{U}$ is the air kerma value obtained from the dosimeter placed under the protection apron on the chest region (TLD 5), converted into $\mathrm{H}_{\mathrm{P}}(10)$.
Studies developed by Padovani et al. ${ }^{(25)}$ and Schultz et al. ${ }^{\text {(26) }}$ have evaluated the appropriateness and accuracy of the effective dose calculation algorithms, and concluded that the Nilklason algorithm is that which best provides the effective dose estimates according to recommendations of the ICRP $75^{(27)}$. On the other hand, studies developed by Järvinen et al. ${ }^{(28)}$ comparing 15 algorithms have demonstrated that the Nilklason algorithm may underestimate the effective dose by a factor of 1.3 ; however, it presents the advantage of requiring data from a dosimeter under the apron and another placed on the thyroid protector. The remaining algorithms require data from more dosimeters, a factor that implies additional costs.

\section{RESULTS}

\section{Dosimetry in patients}

Table 1 presents the irradiation and images acquisition parameters of cerebral angiography procedures performed in adult patients at the hospital under study. The data analysis demonstrates that in the 158 evaluated procedures, the mean exposure time per procedure was 11.1 minutes, with a maximum value of 33.3 minutes. The exposure time is a consequence of the com-

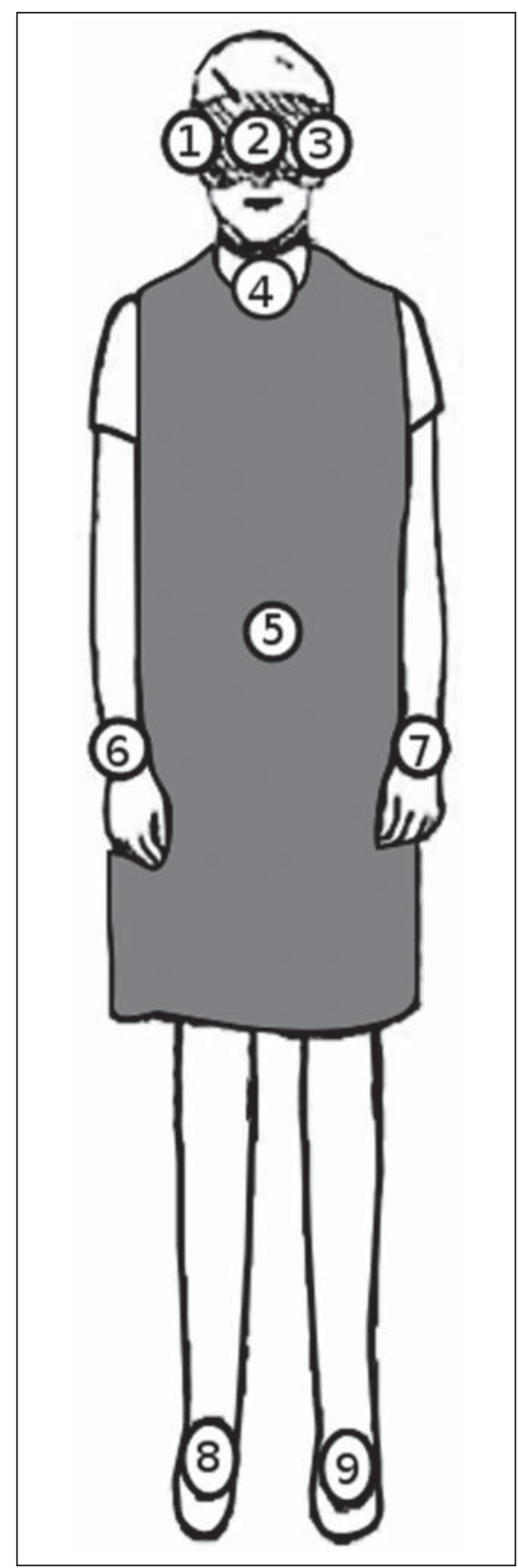

Figure 2. Positioning of dosimeters on the physician.

plexity of the clinical study and of the general physical conditions of the patient. In general, the complexity of the procedures can be characterized by the number and location of the injuries and malformations, as well as by the difficulty of accessing the investigation point. Table 2 shows the mean, minimum and maximum $\mathrm{P}_{\mathrm{KA}}$ and $\mathrm{K}_{\mathrm{a}, \mathrm{r}}$ values obtained according to the exposure mode and to the complete procedures of cerebral angiographies. 
Table 1 Irradiation and acquisition parameters of cerebral angiography performed in adult patients.

\begin{tabular}{|c|c|c|c|c|c|c|}
\hline \multirow[b]{2}{*}{ Mode } & \multicolumn{3}{|c|}{ Irradiation parameters } & \multicolumn{3}{|c|}{ Acquisition parameters } \\
\hline & Tube voltage (kV) & Current (mA) & Pulse width (ms) & Series & Number of images & Time $(\min )$ \\
\hline \multicolumn{7}{|c|}{ Fluoroscopy $(n=158)$} \\
\hline Minimum & 65 & 40 & - & - & - & 1.5 \\
\hline Mean & 71 & 66 & - & - & - & 9.0 \\
\hline Maximum & 89 & 92 & - & - & - & 29.8 \\
\hline \multicolumn{7}{|l|}{$\mathrm{DSA}(n=97)$} \\
\hline Minimum & 63 & 86 & 29 & 4 & 70 & 0.6 \\
\hline Mean & 74 & 333 & 80 & 12 & 256 & 2.0 \\
\hline Maximum & 97 & 803 & 160 & 27 & 1,092 & 6.1 \\
\hline \multicolumn{7}{|c|}{$\mathrm{DSA}+3 \mathrm{D}(n=61)$} \\
\hline Minimum & 63 & 100 & 4 & 8 & 294 & 0.2 \\
\hline Mean & 74 & 354 & 63 & 15 & 603 & 2.0 \\
\hline Maximum & 102 & 803 & 144 & 25 & 1,357 & 4.7 \\
\hline
\end{tabular}

DSA, digital subtraction angiography; 3D, rotational angiographic series for 3D reconstruction; $n$, number of procedures.

\section{Dose on organs}

In the procedures evaluated in the present study, the majority of x-ray beam incidences occur on the posterior region of the head; but many times the beam is directly facing the eyes and thyroid, either because of the necessary incidence to form the image of an injuries close to the sensitive organ, or because of rotational acquisition. For such reason, dosimeters were utilized to estimate the dose on such organs. The results of the air kerma values on the skin entrance surface on the eyes and thyroid regions of adult patients, obtained with the TLDs, are shown on Table 3. One can observe that the mean and maximum air kerma values occur on the left eye region.

\section{Occupational dosimetry}

Figure 3 shows the distribution (showed in a box and whisker plot) of the equivalent doses measured in 37 procedures, at different point on the body of the physicians who performed the procedures. The lower and upper extremities of the rectangle represent the 1 st and 3rd quartiles of the frequency data distribution. The bar crossing the rectangle represents the distribution median, and the mean value is represented by the circle inside the rectangle. The minimum and maximum values are represented by asterisks. The external points are the outliers. The width of the rectangle has no statistical significance.

The effective dose received by the physicians was calculated with the Nilklason
Table 2 Mean, minimum and maximum $\mathrm{P}_{\mathrm{KA}}$ and $\mathrm{K}_{\mathrm{a}, \mathrm{r}}$ values per exposure mode and in the complete cerebral angiography procedure performed in adult patients.

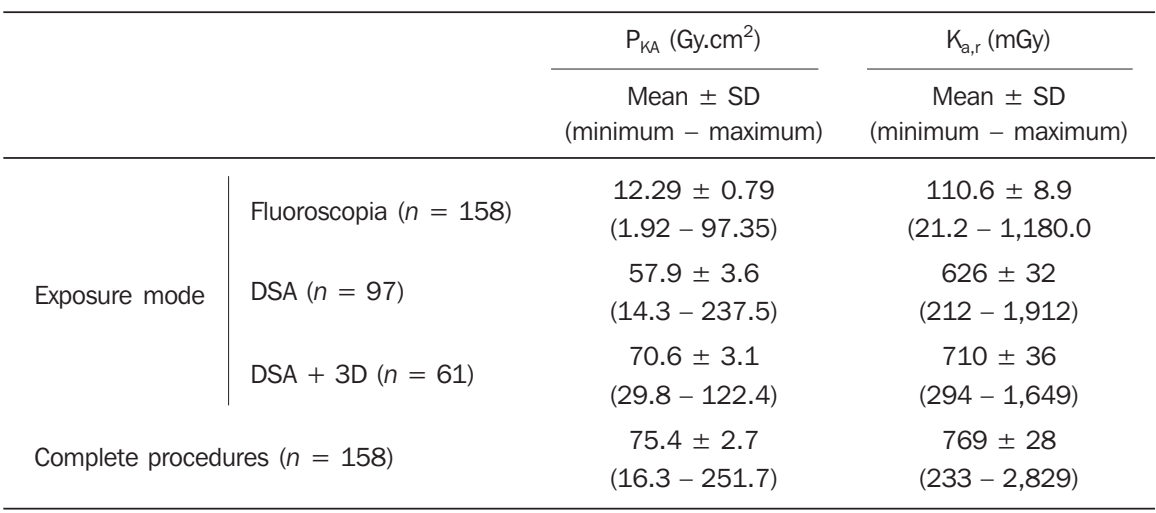

DAS, digital subtraction angiography; 3D, rotational angiographic series for 3D reconstruction; $n$, number of procedures; SD, standard deviation.

Table 3 Mean, minimum and maximum values of air kerma in the eyes and thyroid regions in angiography procedures in adult patients.

\begin{tabular}{cc}
\hline & Air kerma (mGy) \\
\cline { 2 - 2 } Region & Mean \pm SD \\
Left eye & $46.3 \pm 6.1$ \\
& $(0.0-209.5)$ \\
Right eye & $20.1 \pm 3.6$ \\
& $(1.6-90.9)$ \\
Glabella & $7.04 \pm 0.67$ \\
& $(1.7-22.1)$ \\
Thyroid & $6.3 \pm 2.1$ \\
& $(0.0-79.5)$ \\
\hline
\end{tabular}

$\mathrm{SD}$, standard deviation.

algorithm and the results are shown on Figure 4. The mean effective dose at angiography was $2.6 \mu \mathrm{Sv}$ and the maximum, $16 \mu \mathrm{Sv}$.

\section{DISCUSSION}

\section{Dosimetry in patients}

Data on Table1 show that in $61 \%$ of the procedures, image acquisitions were performed by means of digital subtraction, and in $39 \%$, rotational acquisitions were also performed for 3D reconstruction, in addition to the digital subtraction images. In digital subtraction angiographic (DSA) procedures, an image of the region of interest is initially acquired and such an image is digitally subtracted from the images acquired on contrast-enhanced sequences, so both the vascular structure and the vessels of interest can be visualized. In cerebral angiography for the diagnosis of aneurysms, many times, besides the DSA acquisition, series of rotational angiography sequences performed to allow the $3 \mathrm{D}$ recon- 


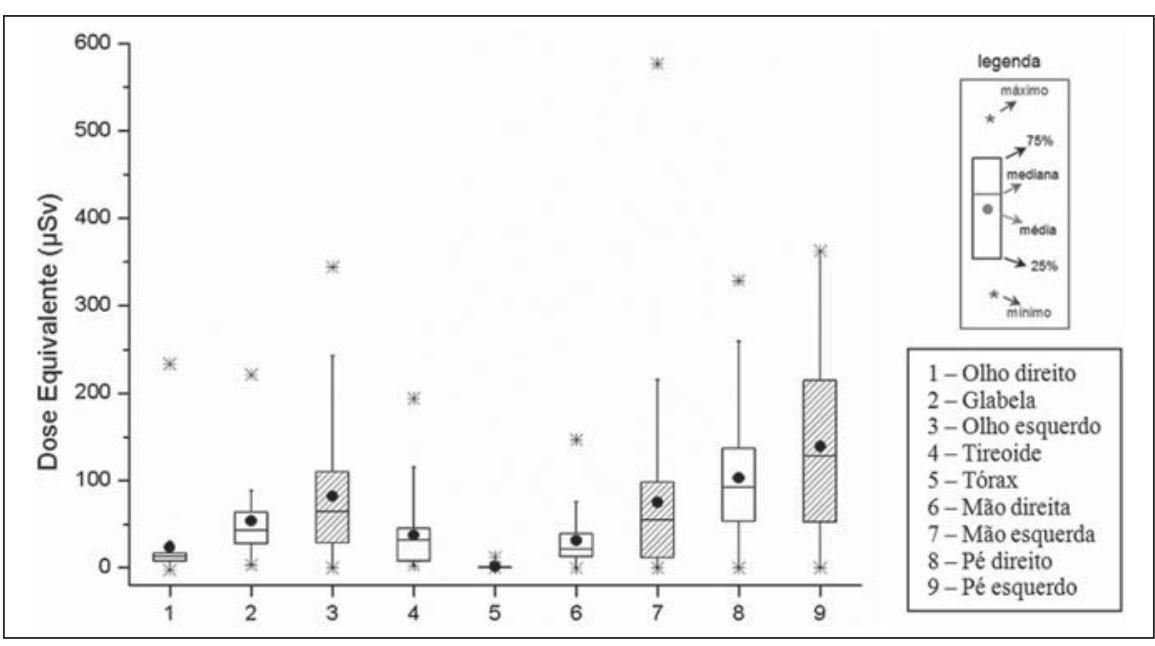

Figure 3. Distribution of equivalent dose in several regions on the body of the physicians who performed cerebral angiographies.

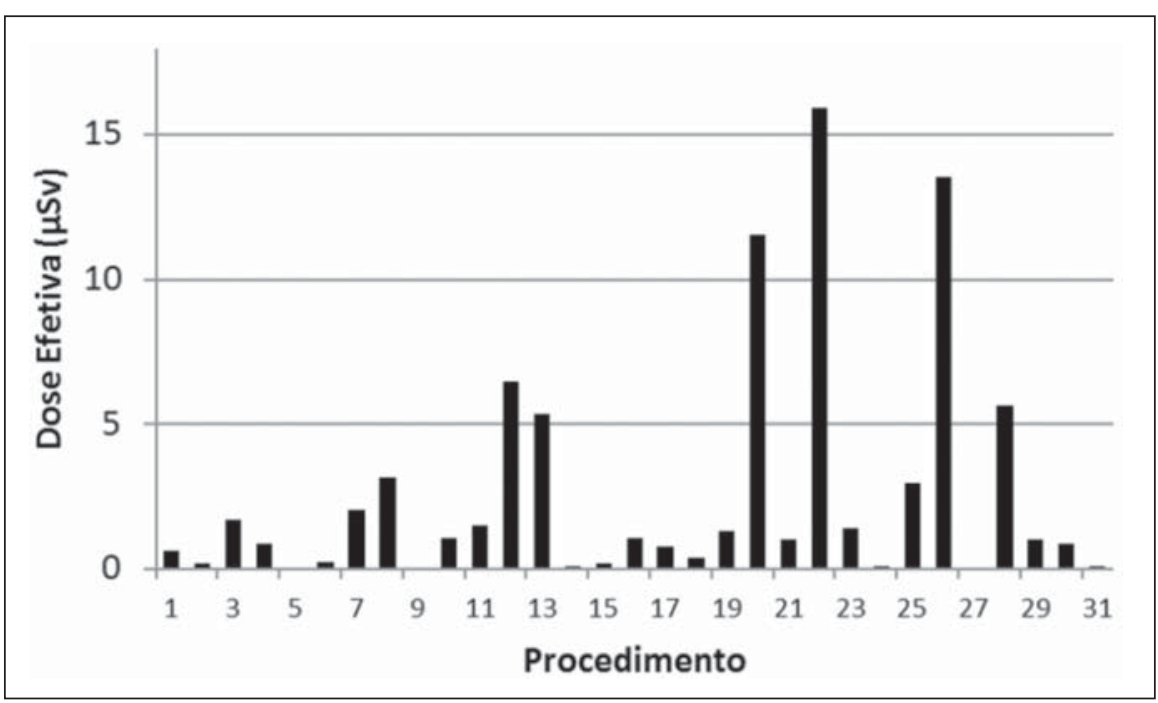

Figure 4. Effective dose on the physicians who performed the cerebral angiography procedures.

struction of the vascular network of the patient. The $3 \mathrm{D}$ reconstruction provides the physician with data to plan the treatment strategy of a patient's vascular abnormality, allowing the visualization of the structures from different angles and the measurement of the volume or of the aneurysm neck (vascular lumen). The number of rotational sequences per procedure depends upon the vascular abnormality found. In 38 procedures, in the largest portion of the second group (DSA + 3D), two rotational sequences were performed for $3 \mathrm{D}$ reconstruction. For 3D reconstruction, a greater number of rotational sequences (four or more) are requires only in cases where the patient has multiple abnormalities located at both sides of the brain, therefore requir- ing contrast medium injection into different brain hemispheres. One also observes that the average number of images in procedures with $3 \mathrm{D}$ reconstructions is higher than twice the average number of images in procedures without rotational acquisition.

The data analysis shows that, in spite of few studies presenting the number of acquired sequences, the mean value found in the present study is similar to the average number of sequences in the study developed by Papageorgiou et al. ${ }^{(29)}$. However, the number of images reported by other studies is more varied because of the wide variability of cases complexities investigated in the diagnosis ${ }^{(30)}$. In studies with biplanar apparatuses, where the images are acquired in two planes by means of two different $\mathrm{x}$-ray tubes, the number of acquired images is greater than the number of acquired images with monoplanar apparatuses $^{(31)}$. However, the mean number of images acquired in the present study is intermediate as compared with those reported by other studies ${ }^{(\mathbf{3 0}, 32)}$, which do not inform on the possible rotational acquisitions, as is the case with the present study ${ }^{(16,29,31)}$.

The analysis of the results on Table 2 shows that the $\mathrm{P}_{\mathrm{KA}}$ value at fluoroscopy in diagnostic procedures represents approximately one sixth of the total $\mathrm{P}_{\mathrm{KA}}$ value of the exam. In the present study, the mean value of $\mathrm{P}_{\mathrm{KA}}$ at fluoroscopy is $16 \%$ of the total $\mathrm{P}_{\mathrm{KA}}$ value of the exam, a value that is similar to that reported by Bor et al. ${ }^{(31)}$ (18\%). It is also possible to observe that the mean values of $\mathrm{P}_{\mathrm{KA}}$ and $\mathrm{K}_{\mathrm{a}, \mathrm{r}}$ in procedures resorting to rotational acquisitions are greater than those in procedures without such type of acquisition. However, the maximum values of $\mathrm{P}_{\mathrm{KA}}$ and $\mathrm{K}_{\mathrm{a}, \mathrm{r}}$ were observed in procedures which did not resort to rotational acquisition. This occurred because of one atypical case of a patient who underwent 27 acquisitions, with 1,092 images, causing such extreme values.

Table 4 shows the mean values and variation range for $\mathrm{P}_{\mathrm{KA}}$ and $\mathrm{K}_{\mathrm{a}, \mathrm{r}}$ values in cerebral angiographic procedures evaluated in the present study and in some studies available in the literature. The values obtained in the present study are in the same order of magnitude of other referenced studies. However, many of such studies were developed with earlier types of apparatuses, which are not equipped with automatically activated copper filters and, therefore, with different radiation spectra. Besides, considering the wide variety of complexities involved in such procedures, one can assert that the collected data are consistent with data in the literature.

\section{Dose on organs}

The results from the measurements with the TLDs demonstrated that the highest kerma value in this study was recorded on the left eye region. The authors assumed that the air kerma value recorded on the skin surface on the lateral region of the eye represents an estimate of the dose absorbed by that eye. Thus, the mean dose absorbed 
Table 4 Mean, minimum and maximum $\mathrm{P}_{\mathrm{KA}}$ and $\mathrm{K}_{\mathrm{ar}}$, values in cerebral angiographies in adult patients obtained in the present study and from the literature.

\begin{tabular}{|c|c|c|c|}
\hline Study & Sample & $P_{\text {KA }}\left(\right.$ Gy. $\left.\mathrm{cm}^{2}\right)$ & $\mathrm{K}_{\mathrm{a}, \mathrm{r}}$ (mGy) \\
\hline Bor et al. (2004) ${ }^{(34)}$ & 47 & $\begin{array}{c}86 \\
(68-149)\end{array}$ & - \\
\hline Rampado et al. (2005) $)^{(32)}$ & 12 & $\begin{array}{c}49 \\
(17-76)\end{array}$ & $\begin{array}{c}400 \\
(147-686)\end{array}$ \\
\hline Bor et al. (2005) ${ }^{(31)}$ & 27 & $\begin{array}{c}46 \\
(8-121)\end{array}$ & - \\
\hline Tsalafoutas et al. (2006) ${ }^{(35)}$ & 43 & $\begin{array}{c}50 \\
(20-146)\end{array}$ & $\begin{array}{c}349 \\
(75-1,864)\end{array}$ \\
\hline Papageorgiou et al. (2007) ${ }^{(\mathbf{2 9})}$ & 33 & $\begin{array}{c}119 \\
(33-261)\end{array}$ & - \\
\hline Alexander et al. $(2010)^{(16)}$ & 432 & 102 & - \\
\hline Present study & 159 & $\begin{array}{c}75.4 \pm 2.7 \\
(16.3-251.7)\end{array}$ & $\begin{array}{c}769 \pm 28 \\
(233-2,829)\end{array}$ \\
\hline
\end{tabular}

by the eyes was $34.1 \mathrm{mGy}$. However, extreme absorbed dose values (210 mGy) were observed. According to data presented by the United Nations Scientific Committee on the Effects of Atomic Radiation (UNSCEAR) ${ }^{(33)}$ for cerebral angiography procedures, the maximum absorbed dose in the eyes was $125 \mathrm{mGy}$. Such a value is lower than those observed in the present study.

It is important to observe that the crystalline lens is a radiosensitive organ, so radiation may induce the development of cataracts in this organ. It is recommended by the International Commission on Radiological Protection (ICRP) ${ }^{(24)}$ that 1.5 Gy is the threshold of cataracts induction dose. However, recent studies have shown that, on account of tissue reactions in the crystalline lens, there are evidences of the occurrence of injuries with lower doses than those previously considered, and that such reactions occur according to individual sensitivity, so in 2011 IRCP lowered the dose threshold for the occurrence of cataract to $0.5 \mathrm{~Gy}^{(\mathbf{1 5})}$. Thus, the doses absorbed by the eyes of the patients evaluated in the present study are sufficiently high to produce tissue reactions, particularly in more sensitive patients.

\section{Occupational dosimetry}

The analysis of the results regarding doses measured on physicians show that feet, hands and eyes on the left side received equivalent doses greater than those on the right side. This occurs due to the physicians' positioning at the right side of the patient with the x-ray tube located at the left.
The apparatus used in the present study is not equipped with protective barriers, such as the lead curtains located at the edge of the table, and the acrylic shield suspended from the room ceiling, which provide protection against scattered radiation on the physicians' work site. The high equivalent dose values in the feet region are due to the absence of the lead curtain. The utilization of such protective device reduces the equivalent dose to the physicians by approximately $90 \%$ according to measurements performed on site.

The equivalent dose values are higher in the feet than in the hands when the x-ray tube is located below the table, and is higher in the hands when the tube is located above the table. In spite of that, it is recommended that the $\mathrm{x}$-ray tube be positioned below the table in order to reduce the dose on both physician's and patient's eyes. In the study developed by Bor et al. ${ }^{(31)}$, the equivalent dose in the region of the feet are lower than those observed in the present study, probably because of the using of protective barriers.

The absorbed doses in the patients' eyes evaluated in the present study were particularly high. Such a fact can lead to an increased incidence of opacities in the crystalline lens and cataracts, as recent studies demonstrate the occurrence of such effects with doses < $500 \mathrm{mGy}$.

\section{CONCLUSIONS}

The results from the present study support the conclusion that the radiation pa- rameters used in cerebral angiography procedures result in high dose values on patients' eye regions, reaching values as high as $345 \mathrm{mGy}$.

Considering the maximum dose value measured on the physicians' eyes which was $344 \mu \mathrm{Sv}$, it is possible to conclude that the maximum number of procedures which the physicians can perform in order not to exceed the annual dose limit should be 1.2 procedure per week. As the mean dose value on the eyes is considered, such number is 4.8 procedures per week. Such high dose values could be reduced by wearing goggles and lead curtains. A change in the radiological protection culture among interventional physicians should be encouraged, in order to contribute to the optimization of the procedures.

\section{REFERENCES}

1. Barros ML, Fernandes DA, Melo EV, et al. Malformações do sistema nervoso central e malformações associadas diagnosticadas pela ultrassonografia obstétrica. Radiol Bras. 2012;45:309-14.

2. Fernandes RCL, Rosso ALZ, Vincent MB, et al. Achados de ultrassonografia transcraniana na doença de Parkinson e no tremor essencial: relato de casos. Radiol Bras. 2012;45:356-8.

3. Coeli GNM, Silva GC, Tiengo RR, et al. Cerebelite aguda com herniação tonsilar: relato de caso. Radiol Bras. 2012;45:244-6.

4. Coeli GNM, Tiengo RR, Silva AC, et al. Neurocisticercose nodular calcificada com sinais de reativação. Radiol Bras. 2012;45:291-3.

5. Sanches P, Yamashita S, Freitas CCM, et al. Glioma cordoide do terceiro ventrículo: descrição de um novo caso. Radiol Bras. 2012;45:288-90.

6. Nogueira-Barbosa MH, Savarese LG, Herrero CFPS, et al. Redundant nerve roots of the cauda equina: review of the literature. Radiol Bras. 2012;45:155-9.

7. Jurno ME, Castro MHA, Lage MA, et al. Síndrome de desmielinização osmótica: relato de caso com evolução favorável. Radiol Bras. 2012; 45:61-2.

8. Gonçalves FG, Barra FR, Matos VL, et al. Sinais em neurorradiologia - Parte 1. Radiol Bras. 2011;44:123-8.

9. Barra FR, Gonçalves FG, Matos VL, et al. Sinais em neurorradiologia - Parte 2. Radiol Bras. 2011;44:129-33

10. Wajnberg E, Rodrigues G, Abud DG. O uso de stents farmacológicos no tratamento da estenose das artérias vertebrais. Radiol Bras. 2011;44:3438.

11. Fletcher DW, Miller DL, Balter S, et al. Comparison of four techniques to estimate radiation dose to skin during angiographic and interventional radiology procedures. J Vasc Interv Radiol. 2002; 13:391-7.

12. Vañó E, González L, Guibelalde E, et al. Evaluation of risk of deterministic effects in fluoroscopically guided procedures. Radiat Prot Dosimetry. 2005;117:190-4. 
13. Moritake T, Matsumaru Y, Takigawa T, et al. Dose measurement on both patients and operators during neurointerventional procedures using photoluminescence glass dosimeters. AJNR Am J Neuroradiol. 2008;29:1910-7.

14. Mooney RB, McKinstry CS, Kamel HA. Absorbed dose and deterministic effects to patients from interventional neuroradiology. Br J Radiol. 2000;73:745-51

15. International Commission on Radiological Protection. Draft report: Early and late effects of radiation in normal tissues and organs: threshold doses for tissue reactions and other non-cancer effects of radiation in a radiation protection context. [acessado em 24 de julho de 2012]. Disponível em: http://www.icrp.org/page.asp?id=116.

16. Alexander MD, Oliff MC, Olorunsola OG, et al Patient radiation exposure during diagnostic and therapeutic interventional neuroradiology procedures. J NeuroIntervent Surg. 2010;2:6-10.

17. Vañó E, González L, Guibelalde E, et al. Radiation exposure to medical staff in interventional and cardiac radiology. Br J Radiol. 1998;71:954-60

18. Ministério da Saúde. Conselho Nacional de Saúde. Resolução No 196 de 10 de outubro de 1996. [acessado em 31 de agosto de 2012]. Disponível em: http://conselho.saude.gov.br/resolucoes/reso_96.htm.

19. Brasil. Ministério da Saúde. Agência Nacional da Vigilância Sanitária. Radiodiagnóstico médico: desempenho de equipamentos e segurança. Brasília: Ministério da Saúde; 2005.

20. Rauch P, Lin PJ, Balter S. Functionality and operation of fluoroscopic automatic brightness con- trol/automatic dose rate control logic in modern cardiovascular and interventional angiography systems: a report of Task Group 125 Radiography/ Fluoroscopy Subcommittee, Imaging Physics Committee, Science Council. Med Phys. 2012, $39: 2826-8$

21. Artis zee/zeego. Manual do utilizador - volume 1. Munich: Siemens AG; 2009.

22. International Electrotechnical Commission Medical electrical equipment - Part 2-43: Particular requirements for the safety of $\mathrm{X}$ ray equipmen for interventional procedures. 1st ed. Geneva; IEC; 2000.

23. Martin CJ. A review of radiology staff doses and dose monitoring requirements. Radiat Prot Dosimetry. 2009;136:140-57.

24. International Commission on Radiological Protection. ICRP Publication 103. The 2007 Recommendations of the International Commission on Radiological Protection. Ann ICRP. 2007;37:1332.

25. Padovani R, Foti C, Malisan MR. Staff dosimetry protocols in interventional radiology. Radiat Prot Dosimetry. 2001;94:193-6.

26. Schultz FW, Zoetelief J. Estimating effective dose for a cardiac catheterisation procedure with single or double personal dosemeters. Radiat Prot Dosimetry. 2006;118:196-204.

27. International Commission on Radiological Protection. General principles for the radiation protection of workers. ICRP Publication 75. Oxford: Pergamon Press; 1997.

28. Järvinen $H$, Buls $N$, Clerinx $P$, et al. Overview of double dosimetry procedures for determination of the effective dose of the interventional radiology staff. Radiat Prot Dosimetry. 2008;129:333-9.

29. Papageorgiou E, Tsapaki V, Tsalafoutas IA, et al. Comparison of patient doses in interventional radiology procedures performed in two large hospitals in Greece. Radiat Prot Dosimetry. 2007; 124:97-102.

30. Urairat J, Asavaphatiboon S, Singhara Na Ayuthaya $S$, et al. Evaluation of radiation dose to patients undergoing interventional radiology procedures at Ramathibodi Hospital, Thailand. Biomed Imaging Interv J. 2011;7:e22.

31. Bor D, Çekirge SC, Türkay T, et al. Patient and staff doses in interventional neuroradiology. Radiat Prot Dosimetry. 2005;117:62-8.

32. Rampado O, Ropolo R. Entrances skin dose distribution maps for interventional neuroradiological procedures: a preliminary study. Radiat Prot Dosimetry. 2005;117:256-9.

33. United Nations Scientific Committee on the Effects of Atomic Radiation. UNSCEAR $2000 \mathrm{Re}-$ port Vol I. Sources and effects of ionizing radiation. Annex D: Medical radiation exposures. UNSCEAR; 2000.

34. Bor D, Sancak T, Olgar T, et al. Comparison of effective doses obtained from dose-area product and air kerma measurements in interventional radiology. Br J Radiol. 2004;77:315-22.

35. Tsalafoutas IA, Goni H, Maniatis PN, et al. Patient doses from noncardiac diagnostic and therapeutic interventional procedures. J Vasc Intery Radiol. 2006;17:1489-98. 